\title{
Sustainability Assessment of Transport Infrastructure Projects: A Review of Existing Tools and Methods
}

\author{
P.C. BUENO, J.M. VASSALLO AND K. CHEUNG
}

ABSTRACT Attempts to integrate sustainability in the decision-making process for transport infrastructure projects continue to gain momentum. A number of tools and methodological frameworks are available — such as rating systems, traditional decision-making techniques, checklists, and different evaluation frameworks and models. While these tools are highly valuable, some practical issues remain unsolved. There is also a need for more standardized tools to appraise the sustainability of transport projects. This paper is a presentation of a review on the current assessment tools of sustainability applied to transport infrastructure projects. The preliminary part of the paper is an explanatory and comparative analysis of the tools and methods in terms of their effectiveness to appraise sustainability. The analysis is a critical evaluation of the current state of the art to identify the limitations of existing approaches, point out new areas of research, and propose a sustainability appraisal agenda for the future.

\section{Introduction}

Since the emergence of the concept of sustainability as an international priority in the 1980s and 1990s, there has been a growing interest in some aspects regarding infrastructure sustainability. Some authors concede that while the concept of sustainability is now better understood in certain contexts, it is still far from being well defined. However, there appears to be a general consensus on the need to achieve economic and social development and protect the environment.

Although there are many approaches aimed at assessing the socio-economic and environmental feasibility of infrastructure projects, there is currently no standardized or commonly agreed methodology offering a reliable measurement of sustainability when appraising and evaluating transport projects over their life cycle - see George (2001) and Stamford and Azapagic (2011). The available literature on sustainable infrastructure - see Dasgupta and Tam (2005), Gilmour, Blackwood, Banks and Wilson (2011), Tsai and Chang (2012) - signals that policy-makers are in need of practical tools and techniques to assess sustainability 
in all the life stages of infrastructure projects. Decision-making processes require comprehensive and reliable appraisal methods.

Current approaches for project appraisal can be broadly grouped into three main categories. The first comprises traditional decision-making techniques and include cost-benefit analysis (CBA), multi-criteria decision analysis (MCDA), life-cycle assessment (LCA), social life-cycle assessment (SLCA), and others. The second includes sustainability rating systems that grade and score infrastructure projects depending on their sustainability performance; and the third covers the frameworks, guidelines, and models used to perform the sustainability appraisal and evaluate infrastructure assets.

From an overall standpoint, these tools are highly valuable for helping decision-makers meet some of their sustainability targets within their specific scope. However, there is still room for improvement in the effectiveness of current assessment tools. Their main weaknesses are that they are biased towards either an environmental or an economic assessment, they fail to address sustainability thoroughly, and are overly focused on certain stages of the project life cycle.

Although traditionally accepted techniques such as CBA, MCDA, and LCA among others - offer valuable support for assessing transport projects, they do not fully address all the components of sustainability (economic, social, and environmental). For example, CBA has still serious problems in evaluating incommensurable goods, whereas MCDA can introduce subjectivity when evaluating the weights selected to rank different criteria. Rating systems and models are useful to rank and compare projects, but focus mainly on environmental aspects and on the construction stage of the project. Despite the usefulness of rating systems, the frameworks, and models are not designed to assist planners in the decision-making processes when selecting the most suitable design for sustainability.

This research is a review of existing tools and methods related to sustainability assessment of transport infrastructure projects. Our primary goal was to identify and evaluate the appropriateness of available tools for assessing transport infrastructure projects according to the sustainability principles. This research work is not an attempt to validate whether current assessment tools are good by themselves. Rather, the specific objectives of this research are: first, to evaluate the performance of appraisal tools when measuring sustainability; second, to provide a comparative review of the different characteristics, scope, application, and methodological constrains of these tools and methods; and third, to identify challenges to improve the sustainability assessment of transport projects in the future. To this end, a wide overview is given of the state of the art for measuring sustainability. Finally, we propose five major research needs to improve the appraisal of sustainability in dealing with transport projects.

The paper is structured as follows. In Section 2, after the introduction, there is a review of the concept of sustainability followed by an examination of the literature regarding tools and appraisal methodologies for sustainability assessment of transport infrastructure projects. To this end, we follow a systematic approach aimed at identifying key aspects that are not being incorporated into the current methods and sustainability assessment practice. On the basis of the literature review, in this section we outline five major challenges to improve sustainability appraisal of transport projects and examine how these challenges can be implemented in practice. Finally, Section 3 of the paper includes a set of 
conclusions, final reflections, and recommendations for future research areas in this field.

\section{Literature Review}

\subsection{Sustainability: General Concept and Definitions}

The concept of sustainability was launched in 1972 at the United Nations (UN) Conference on the Human Environment held in Stockholm, which was the first international symposium called to discuss exclusively environmental issues. The Brundtland Commission subsequently produced the most widely used of all the definitions of sustainable development: "sustainable development is development that meets the needs of the present without compromising the ability of future generations to meet their own needs" (Brundtland World Commission on Environment and Development, 1987, p.1). These were followed by other highranking conferences and events in association with the UN. The progressive evolution of these conferences reveals "a shift in the political debate from a primary emphasis on environmental issues, through a shared focus on environmental, social and economic development" (Paul, 2008, p. 579).

Several definitions of sustainability can be found in the literature, although most focus on specific fields, such as economy, ecology, and the environment (Gilmour et al., 2011; Parkin, Sommer, \& Uren, 2003; Radermacher, 1999). Since each discipline has its own explanation and semantic features, definitions tend to differ and "not a single reference presented a feasible definition of sustainable development which could incorporate all aspects of the concept commission's report under investigation, and provide no ideal understanding of this concept" (Ciegis, Ramanauskiene, \& Martinkus, 2009, p. 30). However, while there may be a debate about the universal definition of sustainability, there are some commonly agreed principles when considering actions to promote sustainable transportation - see, for example, National Cooperative Highway Research Program-NCHRP (2011).

Sustainable development is still seen as a complex issue that defies definition for practical purposes. According to Gilmour et al. (2011), "it is generally accepted that the real challenge lies in understanding how to put it into practice: that is, to operationalize sustainability" (p. 16). Sustainable construction is defined as a building process that incorporates the basic principles of sustainable development (Chaharbaghi \& Willis, 1999; Parkin, 2000). These processes should comply with the objectives of environmental responsibility, social awareness, and economic profitability (Shelbourn et al., 2006).

\subsection{Assessing Sustainability of Transport Projects}

As stated above, there is no common understanding of what constitutes sustainability in real-life projects, both as a concept and in a practical sense. This section provides a definition of sustainability of transport projects and also explores the means whereby sustainability can be addresed in assessment.

For the purpose of this paper, a transport project will be considered "sustainable" when it contributes to favour economic development and fulfil the transportation needs of the society in a manner consistent with natural laws and human values. Beyond this definition, we believe that there are two other essential 
points to take into account when dealing with sustainability. First, the fact that the measure of sustainability is sensitive to the economic, social, and environmental context where the project is located. And second, a proper definition of "sustainable transport projects" must include the whole life cycle; from conception through construction, operation, maintenance, and the recycling/reuse stage.

The last mentioned element of the sustainability concept, based on the Brundtland definition and other academic references - see, for example, Munasinghe, Sunkel, and Miguel (2001), Sijtsma (2006) - reinforces the adoption of a "long-term approach" for the purpose of sustainability assessment. Hence, impacts to be considered for transport projects might be related to the construction (e.g. investment costs of the project, generally comprising land acquisition, design/legal/administration and construction costs); maintenance (e.g. air pollution costs covering short-term air quality effects caused by maintenance activities); operation of the facility (e.g. vehicle operating cost, including fixed costs, and operating costs); and the recycling/reuse stage (e.g. energy consumed by using fuel and electric power in the process of transporting and recycling).

On the other hand, there is also a dilemma about the purpose of sustainability: whether it is really a matter for decision-making or it is more a part of an evaluation ex post. In the literature this fact has not yet been treated in detail yet. However, some authors have acknowledged that it is good to consider sustainability at the planning stage. For example, Reid, Davis, and Bevan (2012) admitted that "the opportunities to incorporate sustainability vary and eventually diminish as a project moves through the project life cycle". Tsai and Chang (2012) in their turn pointed out that "Great potential reductions in operations' sustainable impacts could be made if sustainability is considered early in planning and design".

As a consequence, we can claim that the primary purpose of sustainability assessment should start with the appraisal and decision-making, because, at this point, decision-makers have great influence on the future sustainability performance of the project. In other words, implementing sustainability principles become more effective at the planning stage than as part of an ex-post evaluation. However, verifying the sustainability of an already existing project can be useful to "recycle" best practices and procedures in future projects, due to the retrospective character it implies. Despite sustainability should be necessarily part of a primarily an ex ante assessment, it can also be used for other purposes. Figure 1 explores the means whereby sustainability can be used in assessment and clarifies how its role fits with the decision-making and the implementation processes of an infrastructure project (Anderson \& Muench, 2013; Cundrič, Kern, \& Rajkovič, 2008; Dasgupta \& Tam, 2005; Gambatese \& Rajendran, 2005; Gühnemann, Laird \& Pearman, 2012; Lee, Edil, Benson \& Tinjum, 2011; Ugwu, Kumaraswamy, Wong, \& Ng, 2006).

\subsection{Current Methods and Techniques for the Assessment of Transport Infrastructure Projects. How do they Address Sustainability?}

Transport infrastructure projects are appraised in practice through a number of tools or methodological frameworks that include the concept of sustainability to a greater or lesser extent. These methods and tools encompass the traditional 


\begin{tabular}{|c|c|c|}
\hline \multirow[b]{2}{*}{$\begin{array}{l}\text { Corresponding project } \\
\text { lifecycle stage }\end{array}$} & $\begin{array}{c}\text { ex-ante sustainability } \\
\text { evaluation }\end{array}$ & ex-post sustainability evaluation \\
\hline & PLANNING & $\begin{array}{l}\text { CONSTRUCTION\& } \\
\text { RE-CONSTRUCTION }\end{array}$ \\
\hline Sustainability is part of & $\begin{array}{l}\text { The appraisal and the decision- } \\
\text { making process }\end{array}$ & The monitoring process, for evaluation purposes \\
\hline Sustainability aims at & $\begin{array}{l}\text { Supporting the selection of the } \\
\text { alternative option that } \\
\text { maximizes beneficial outcomes } \\
\text { on all dimensions of } \\
\text { sustainability }\end{array}$ & $\begin{array}{l}\text { Quantifying sustainable practices associated with the } \\
\text { construction and maintenance processes. In these } \\
\text { stages, sustainability can be used to certify and } \\
\text { monitor transport projects }\end{array}$ \\
\hline $\begin{array}{l}\text { Means by which } \\
\text { sustainability can be } \\
\text { used: } \\
\text { A ROAD PROJECT } \\
\text { EXAMPLE }\end{array}$ & $\begin{array}{l}\text { A process where sustainability is } \\
\text { used to provide guidance on } \\
\text { appraisal and decision-making: } \\
\text { (i) After identifying project } \\
\text { impacts, calculate the global } \\
\text { sustainability evaluation of each } \\
\text { alternative, for example using a } \\
\text { multi-criteria approach } \\
\text { (ii) Obtain the ranking order of } \\
\text { alternatives and select the } \\
\text { alternative with the highest } \\
\text { sustainability performance }\end{array}$ & $\begin{array}{l}\text { Sustainability as a monitoring tool can be used in } \\
\text { different processes to: } \\
\text { (i) Evaluate the project against original objectives that } \\
\text { it was designed for } \\
\text { (ii) Assess, compare and award the existing road, } \\
\text { depending on its performance against relevant } \\
\text { sustainability criteria previously defined, for example } \\
\text { by a rating system for roads (e.g. Greenroads, } \\
\text { GreenLITES) } \\
\text { (iii) Improve current practices in roadway construction } \\
\text { and do more than the minimum requirements } \\
\text { (iv) Suggest best practices and procedures in future } \\
\text { road projects, due to the retrospective character it } \\
\text { implies }\end{array}$ \\
\hline $\begin{array}{l}\text { Practical application } \\
\text { examples }\end{array}$ & $\begin{array}{l}\text { Gühnemann et al. (2012); Cundrič, } \\
\text { Kern, \& Rajkovič (2008); Ugwu, } \\
\text { Kumaraswamy, Wong, \& Ng } \\
\text { (2006); Dasgupta \& Tam (2005) }\end{array}$ & $\begin{array}{l}\text { Lee, J., Edil, T., Benson, C., \& Tinjum, J. (2011); } \\
\text { Gambatese \& Rajendran, (2005); Anderson \& } \\
\text { Muench (2013) }\end{array}$ \\
\hline
\end{tabular}

Figure 1. Sustainability as an ex ante/ex post tool.

methodologies as well as a number of current sustainability tools. We classify the current tools and methods in the following way:

(1) Project appraisal methods for decision-making. In this paper we focus on CBA and multi-criteria approaches. Despite the fact that some of these tools were not initially designed for sustainability assessment, we consider them in the analysis because they are until now the most commonly used techniques for decision-making processes in transport project appraisal, and they are evolving towards the introduction of sustainability aspects.

(2) Techniques for assessing environmental/social impacts. Approaches to assess the environmental and social impacts of transport project options that are evaluated here include: the LCA and the SLCA. Although these techniques address mostly environmental or social topics, we took them into account since they are often combined with other tools for a complete sustainability assessment.

(3) Sustainability assessment methodologies, including rating systems and frameworks and appraisal guidelines. The analysis includes sustainability selfevaluation tools developed for civil infrastructure in general (such as the Civil Engineering Environmental Quality and Assessment Scheme CEEQUAL, the infrastructure rating and recognition system developed by the Zofnass Program for Sustainable Infrastructure and the Institute for Sus- 
tainable Infrastructure - Envision ${ }^{\mathrm{TM}}$ and the Leadership in Energy and Environmental Design Rating System for Neighborhood Development LEED®) as well as rating systems focused on roads (e.g. the voluntary rating system developed by the University of Washington and CH2M HILL - Greenroads ${ }^{\mathrm{TM}}$, and, the Green Leadership in Transportation Environmental Sustainability rating program - GreenLITES). In addition, we also included in the analysis frameworks and appraisal guidelines for sustainability assessment of infrastructure projects.

Current transport-related sustainability methods and techniques are introduced in the following sections from a sustainability perspective. By highlighting their strengths and weaknesses, our aim is to examine how they work and identify whether existing tools provide a suitable framework to integrate sustainability into existing appraisal processes. To analyse these tools and methods that can be used for the sustainability assessment of transport infrastructure projects, we reviewed reporting guidelines, frameworks, and more than 100 relevant academic studies.

\subsubsection{Project appraisal methods}

2.3.1.1. Cost-benefit analysis. CBA is the most widely used method to support decision-makers in appraising transport projects. It is a known and widely used technique that enables the comparison among alternatives under the objective of maximizing social welfare. This approach is generally employed as an ex ante method and it is based on the possibility of monetizing the user benefits (e.g. travel time savings) as well as the cost of investment and other "negative" effects (e.g. energy consumption, resources use, and $\mathrm{CO}_{2}$ emissions). There are numerous textbooks and academic papers dealing with the theory and practice of this methodology - see, for example, (Gühnemann et al. (2012), Hyard (2012), Tudela, Akiki, and Cisternas (2006).

From a general perspective, the role of the CBA has been often discussed in the academic literature. Some authors support the adequacy of applying the CBA to evaluate public projects, and study its influence (e.g. Grant-Muller, Mackie, Nellthorp, \& Pearman, 2001; Pearce \& Nash, 1981), while others discuss some disagreements about its usefulness as a decision-making support tool and review the problems surrounding the use of this tool in the appraisal of large-scale infrastructure projects (e.g. Jones, Moura, \& Domingos, 2014; Vickerman, 2007).

It is not the aim of this section to carry out an exhaustive critique of the wellknown CBA method, but rather to evaluate its performance in the context of accounting for sustainability. Thus some key pros and cons together with a discussion about how sustainability can be included in the assessment of transportation infrastructure projects are presented in the following paragraphs.

First, when evaluating sustainability, CBA offers valuable support since it is a rigorous, transparent, and formal appraisal tool. In general, a substantial number of authors have argued that CBA can perform a comprehensive and useful methodology in the decision-making processes - see Beria, Maltese, and Mariotti (2011), Tudela et al. (2006). It is particularly suitable to support decision-making of infrastructure since it provides a "tangible and rational" judgement of benefits and costs from different alternatives of the project.

Conversely, there has been considerable research aimed at identifying substantive problems when appraising the sustainability of transport projects with a CBA. 
By examining the prospect of CBA application in promoting or demoting sustainable development we found "abundant arguments disfavouring the application of CBA, represented by limitations such as: (i) trying to evaluate what are often not 'evaluable,' that is, non-economic values, and (ii) limited considerations regarding distributional equity (including inter-temporal equity)" (Omura, 2004, p. 44).

Given these drawbacks, we can claim that CBA suffers from the objectivity/ subjectivity dilemma. In other words, the technique can be classified as "pseudo-objective" since it still has difficulties in quantifying non-market goods - see Mackie and Preston (1998), Niemeyer and Spash (2001). Examples in the transport context include the treatment of impacts such as travel-time savings - see, for example, Van Wee (2007) - $\mathrm{CO}_{2}$ emissions - see, for example, Mandell (2013) - and road accidents - see, for example, Bristow and Nellthorp (2000). Furthermore, for the items that cannot be bought and sold in the market, the inter-temporal aggregation is still contentious, in that some authors suggest environmental discount rates - see Almansa and Calatrava (2007) - others estimate monetary impacts and apply traditional discount rates, while others opt for simple aggregation, even though the impacts may extend over a long period of time.

It is therefore interesting to mention that discounting has traditionally been a controversial issue since results are generally quite sensitive to the discount rate. Previous limitations have long been a subject of intense debate among economists. This fact suggests the need of a proper incorporation of this uncertainty throughout the analysis. In this respect, Almansa and Calatrava (2007) conducted a broad analysis of the discounting problem by adapting the CBA analytical theory in the context of sustainability assessment.

The tool is not able to include the triple bottom line in a precise and narrow manner since the monetization process is questionable for these intangible items. When the approach tries to price "priceless things", there is a greater degree of uncertainty in measurement, forecasting, and evaluation. Furthermore, a typical CBA does not consider the full life cycle of a project, for example, end of life aspects are rarely included - see further detail about weaknesses of the CBA in Jones et al. (2014).

2.3.1.2. Multi-criteria decision analysis. The multi-criteria technique is a suitable decision-making methodology for "addressing complex problems featuring high uncertainty, conflicting objectives, different forms of data and information, multiple interests, and perspectives, and the accounting for complex and evolving biophysical and socio-economic systems" (Kowalski, Stagl, Madlener, \& Omann, 2009, p. 1065). It can be described as a set of techniques rather than a single approach — see Munda, Nijkamp, and Rietveld (1998). The use of MCDA for different purposes has been increasing over the years. There are several studies where this approach has been applied in the field of transport (Cheng \& Li, 2005; Friesz, Tourreilles, Han, \& Fernandez, 1980; Frohwein, Lambert, Haimes, \& Schiff, 1999; Giuliano, 1985; Iniestra \& Gutiérrez, 2009; Khorramshahgol \& Steiner, 1988). An extensive review of the MCDA method can be found in Huang, Keisler, and Linkov (2011), Kabir, Sadiq, and Tesfamariam (2013), Wang, Jing, Zhang, and Zhao (2009).

A number of authors have suggested that MCDA is the most appropriate tool to adopt for decisions based on an integrated sustainability appraisal (Janic, 2003; Tudela et al., 2006; Walker, 2010). For addressing sustainability the MCDA 
usually includes the identification of sustainability criteria, the evaluation for each alternative ${ }^{1}$, the assignment of weighting coefficients to the criteria, and finally the sustainability evaluation by using a method for ranking the alternatives.

MCDA offers a number of advantages for policy and planning analysis, compared to conventional economic welfare techniques (Munda, 1995). This tool is relevant when promoting public participation and enabling stakeholder involvement. With the MCDA method, several criteria can be taken into account simultaneously - including those difficult to monetize or quantify (Thomopoulos, Grant-Muller, \& Tight, 2009).

A short example may serve to illustrate the advantage of accounting for multiple dimensions. As explained above, when appraising the sustainability of roadway projects, it is necessary to identify and evaluate sustainability criteria for each alternative. Table 1 presents a set of major items to be considered for the sustainability appraisal of highway projects over their life cycle. Appropriate criteria to measure sustainability should take into account economic efficiency, environmental protection, and also social aspects such as equity. It is essential to note, however, that despite some of these criteria can be monetized, but most of them are difficult to do it. Given the need to holistically capture economic, environmental, and social impacts, the multi-criteria scheme could be very effective since it accomplishes the goal of being multi-disciplinary. In addition, the MCDA scheme should be used to account for a more comprehensive range of impacts, taking advantage of recent advances in the environmental and social assessment fields of research.

However, despite the fact that MCDA can explicitly deal with different components of sustainability, the extensive study of multi-criteria techniques for trans-

Table 1. Sustainability criteria for highway projects throughout their life cycle

Sustainability

component Sustainability criteria Description

\begin{tabular}{|c|c|c|}
\hline \multirow[t]{5}{*}{ Economic } & $\begin{array}{l}\text { Infrastructure costs (construction/ } \\
\text { maintenance/operating) }\end{array}$ & Monetized (with market prices) \\
\hline & Travel time cost/saving & Monetized (Ongoing debate) \\
\hline & Vehicle operating cost & Monetized (with market prices) \\
\hline & Accident cost/saving & Monetized (Ongoing debate) \\
\hline & Macroeconomic impacts & Difficult to quantify, difficult to monetize \\
\hline \multirow[t]{5}{*}{ Environmental } & $\begin{array}{l}\text { Energy consumption, resource } \\
\text { use and } \mathrm{CO}_{2} \text { emissions }\end{array}$ & Quantified but difficult to monetize \\
\hline & $\begin{array}{l}\text { Habitat fragmentation and } \\
\text { negative effects on species }\end{array}$ & Quantified but difficult to monetize \\
\hline & Air pollution & Quantified but difficult to monetize \\
\hline & Noise pollution & Quantified but difficult to monetize \\
\hline & $\begin{array}{c}\text { Landscape degradation and } \\
\text { negative visual impacts }\end{array}$ & Quantified but difficult to monetize \\
\hline \multirow[t]{5}{*}{ Social } & Community disruption & Quantified but difficult to monetize \\
\hline & $\begin{array}{l}\text { Impacts on businesses and } \\
\text { community services }\end{array}$ & Quantified but difficult to monetize \\
\hline & Employment and labour standards & Quantified but difficult to monetize \\
\hline & Distributive effects of the project & Difficult to quantify, difficult to monetize \\
\hline & $\begin{array}{l}\text { Occupational and community } \\
\text { health and safety }\end{array}$ & Quantified but difficult to monetize \\
\hline
\end{tabular}


port projects has highlighted issues that require further analysis including: the inherent subjective qualitative assessment, the complexity of identifying impacts to be included and its measurement method, and the obtaining of weights to criteria (Browne \& Ryan, 2011). In fact, the use of weights is the main unresolved matter of this methodology. It has to do with the transparency of judgements and their influence on the final results of a multi-criteria problem. This weakness has been the subject of severe criticisms by a number of authors - see, for example, Browne and Ryan (2011), Hobbs and Horn (1997).

To sum up, the multi-criteria approach provides a proper structure when dealing with sustainability of transport projects, but the assessment process tends to become highly subjective. In practice, the process for obtaining the relative importance of criteria might appear questionable. The "black box" concept should be considered as an important issue since it might cause a loss of credibility. In fact, "due to a lack of procedures for aggregating the evaluations of the individual criteria and unregulated weights that were left to the whim of the decision-takers" (Sayers, Jessop, \& Hills, 2003); some governments — such as France - have moved away from the MCDA and returned to the "monetising approach".

As a result, the multi-criteria analysis involves a certain level of subjectivity (Barfod, Salling, \& Leleur, 2011; Beria et al., 2011). Qualitative assessment and the imputation of value-laden weightings to assumptions may lead to subjective biasing - see Munda (2004) and White and Lee (2009). According to Sayers, Jessop, and Hills (2003), the real challenge lies in finding a balance between these consistency and flexibility.

\subsubsection{Techniques for assessing environmental/social impacts}

2.3.2.1. Life-cycle assessment. LCA is a technique for assessing the environmental impacts of a product, activity, or process. The use of this analysis for decision-making involves an environmental performance assessment of the whole life cycle from "cradle to grave", including material extraction, manufacturing, transport, and distribution, product use, service and maintenance, and endof-life such as reuse, recycling, energy recovery, and final waste handling (Stripple \& Erlandsson, 2004).

This approach has been widely used in the decision-making process, applied to a variety of fields including: energy and transport - for example, Matsuhashi, Hikita, and Ishitani (1996), Raluy, Serra, and Uche (2005) and Tahara, Kojima and Inaba (1997); water - for example, Dennison, Azapagic, Clift, and Colbourne (1998); and chemical sectors - for example, Ophus and Digernes (1996); among others. Despite the approach has been used for quantifying the environmental efficiency of some transport infrastructure projects, most of the studies have been focused on road infrastructure projects — see, for example, Stripple (2001).

The LCA usually provides valuable input for sustainability assessment since it constitutes a versatile tool that quantifies the environmental efficiency based on a "life-cycle approach". As some authors admitted - see Baker and Lepech (2009), Keoleian and Spitzley (2006) - in practice, the LCA has become a common tool for the evaluation of the environmental performance since it provides metrics that can be used in the sustainability assessment of transport projects.

On the other hand, according to Reap, Roman, Duncan, and Bras (2008), although the analysis technique offers a coherent and comprehensive approach to environmental assessment of product systems, it still "suffers from problems 
that degrade accuracy and increase uncertainty of assessment results". For example, these authors identified 15 major problem areas that reduce the accuracy of the tool, including difficulties with selecting impact categories, indicators and models, spatial variation, subjective values using weightings and problems in monetization methods, among others. In this respect, a broad review and explanation of uncertainties in life-cycle assessment was performed by Baker and Lepech (2009).

When accounting for sustainability, as some researchers have shown, the LCA has some drawbacks and still needs some improvements to increase its accuracy - see Loiseau, Junqua, Roux, and Bellon-Maurel (2012). For example, in this approach, all sustainability criteria are not fully incorporated since its primary purpose is limited to the assessment of the environmental consequences of a given activity. There is a need for integrating LCA into other appraisal tools, but LCA by itself is an incomplete tool to assess all the three dimensions of sustainability. Consequently, LCA can be regarded as a particular step to define a complete sustainability impact assessment tool.

From the literature, it is found that there are several limitations with "environmental tools" since they have a "general objective of encouraging greater environmental responsibility within the construction industry, but not toward sustainability as a whole" (Treloar, Love, \& Crawford, 2004, p. 43). Furthermore, when applying LCA to transport projects, it is usually confined to materials and engine alternatives for construction machinery. It does not consider how energy consumption varies with different design parameters. As a result, the significant changes in the environmental effects captured through the LCA, scarcely include the design phase of the facility.

2.3.2.2. Social assessment approaches. The evaluation of social impacts has been implemented by using several approaches. However, these approaches have often been less well-developed than economic and environmental assessment approaches. As an example, today there is no standardized method to evaluate social and distributional effects of transport projects.

Particularly, the inclusion of social aspects into LCA - called the SLCA - is still under progress. According to Jørgensen, Le Bocq, Nazarkina, and Hauschild (2008), SLCA methodologies are in an early stage of development where consensus building still has a long way to go. These authors stated that "some agreement regarding which impacts are most relevant to include in the SLCA in order to cover the field sufficiently seems paramount if the SLCA is to gain any weight as a decision support tool" (p. 96). Even though social impacts are considered within the scope of an impact assessment - see European Commission (2009) - greater attention is still given to economic and environmental aspects.

A study developed by the Evaluation Partnership and the Centre For European Policy Studies (TEP \& CEPS, 2010) found some limitations that have to be addressed in order to set up an effective social assessment. They are the following:

(1) The term "social impacts" is potentially too broad and has not been well defined yet;

(2) The lack of appropriate tools to assess social impacts quantitatively is one of the most frequently cited challenges to effectively carry out social impact assessment. Most social assessments remain purely qualitative, and often very superficial. 
2.3.3. Rating systems and certification tools. Rating systems and certification tools are a collection of best practices, which may be useful for practitioners in incorporating sustainability principles into projects. Best practices are typically associated with a common metric, usually called points or credits.

This metric quantifies each best practice in a common unit. In this way the diverse measurement units of sustainability best practices (e.g., pollutant loading in stormwater runoff, pavement design life, tons of recycled materials, energy consumed/saved, pedestrian access, ecosystem connectivity and even the value of art) can all be directly compared. (Veeravigrom, Muench, \& Kosonen, 2015, p. 4)

Some rating systems weigh every best practice equally, while others establish different levels of importance for each best practice.

The sustainability evaluation tools "are typically produced by reputable governmental or non-governmental institutions, sometimes in collaboration with academia. They are intended to assess, compare, and award a planned or existing facility, depending on its performance against relevant sustainability criteria" (International Federation of Consulting Engineers, 2012, p. 17). According to Muench, Armstrong, and Allen (2012), rating systems are appealing for the following basic reasons:

(i) they provide a common metric for the entire range of sustainable solutions, (ii) they measure sustainability and thus make it manageable, (iii) they allow for straightforward communication of sustainability goals, efforts and achievement, and (iv) they provide a reasonable context within which designers, contractors and material suppliers can be innovative in their solutions. (Muench et al., 2012, p.4)

There are specific rating schemes for evaluating sustainability of buildings, road construction projects and civil engineering works. As mentioned by some authors - see Clevenger, Ozbek and Simpson (2013), Simpson, Clevenger, Ozbek, Kohlman and Atadero (2014), the civil engineering rating systems are based on the building rating schemes which are well established. Very few scientific studies providing a review of sustainability rating systems are found in the literature see Clevenger et al. (2013), Reid et al. (2012), Samberg, Bassok and Holman (2012). Some recent papers provide detailed explanation of the application of different sustainability tools to real case studies and its potential use - see, for example, Lester and Olmsted (2015), Sturgill, Dyke, McCormack, and Kreis (2015).

The rating and certification tools analysed as part of this research are listed in Table 2. They are tools in the field of transport and civil infrastructure as well as some other specialized tools for road projects. While rating systems share a number of common characteristics, they also have unique features since they emphasize different sustainability aspects. Table 2 includes eight prominent emerging sustainable rating systems and highlights the differences among them.

Similar to what happens with building sustainable tools (Reed, Bilos, \& Wilkinson, 2009), existing or emerging certification tools for transport projects concentrate on the USA and the UK. However, some of these well-known systems are starting to be applied in other countries as well - see, for example, the InterAmerican Development Bank (2015). In this respect, the World Bank 
Table 2. Different rating and certification tools

\begin{tabular}{|c|c|c|c|}
\hline Sector & Tool & $\begin{array}{l}\text { Country } \\
\text { of origin }\end{array}$ & Main characteristics \\
\hline \multirow[t]{3}{*}{$\begin{array}{l}\text { All } \\
\quad \text { infrastructure }\end{array}$} & CEEQUAL & UK & $\begin{array}{l}\text { - The Civil Engineering Environmental Quality and Assessment Scheme (CEEQUAL) was developed by: The Institution of } \\
\text { Civil Engineers (ICE) } \\
\text { - Categories included: 9. project strategy, project management, people and communities, land use and landscape, } \\
\text { communities, historic environment, ecology and biodiversity, water environment, physical resources, transport } \\
\text { - Key features: can be used in new locations outside the UK. A key feature of CEEQUAL International is the guidance } \\
\text { provided for a new weighting exercise specific to the new local area of the project. There is also a scheme for assessing term } \\
\text { contracts }\end{array}$ \\
\hline & Envision & USA & $\begin{array}{l}\text { - The infrastructure rating and recognition system Envision }{ }^{\mathrm{TM}} \text { was developed by: the Zofnass Program for sustainable } \\
\text { infrastructure based at the Harvard Graduate School of Design and the Institute for Sustainable Infrastructure (ISI) } \\
\text { - Categories included: } 5 \text {. quality of life, leadership, resource allocation, natural world, climate and risk } \\
\text { - Key features: It has a unique category of climate and risk that accounts for natural hazards, and climate change mitigation } \\
\text { and adaptation. Envision includes some planning elements in their rating - part of planning is choosing the right project }\end{array}$ \\
\hline & LEED & USA & $\begin{array}{l}\text { - The Leadership in Energy and Environmental Design Rating System for Neighborhood Development }\left(\text { LEED }^{\circledR}\right) \text { was } \\
\text { developed by: The US Green Building Council } \\
\text { - Categories included: 7. sustainable sites, water efficiency, energy and atmosphere, materials and resources, indoor } \\
\text { environmental quality, innovation in design, regional priority } \\
\text { - Key features: is the most accepted and widespread sustainable rating system. It has strong emphasis on building design. It } \\
\text { provides one definition, widely accepted by the building industry, for what currently constitutes a "green building"b }\end{array}$ \\
\hline
\end{tabular}

(Continued) 
Table 2. Continued

\begin{tabular}{|c|c|c|c|}
\hline Sector & Tool & $\begin{array}{l}\text { Country } \\
\text { of origin }\end{array}$ & Main characteristics \\
\hline \multirow[t]{5}{*}{ Transport } & GreenLITES & USA & $\begin{array}{l}\text { - The Green Leadership in Transportation Environmental Sustainability rating program (GreenLITES) was developed by: } \\
\text { The New York State Department of Transport } \\
\text { - Categories included: 5. sustainable sites, water quality, material resources, atmosphere, innovation } \\
\text { - Key features: strong emphasis on community impacts. Context specific (climate, guidance) }{ }^{c}\end{array}$ \\
\hline & Greenroads & USA & $\begin{array}{l}\text { - The voluntary rating system Greenroads }{ }^{\mathrm{TM}} \text { was developed by: The University of Washington and CH2M HILL } \\
\text { - Categories included: } 7 \text {. project requirements, environment and water, access and equity, construction activities, materials } \\
\text { and resources, pavement technologies, custom credits } \\
\text { - Key features: tends to focus on material and design concerns, with a separate category for pavement. The system is oriented } \\
\text { towards environmental aspects of projects, although access and equity are addressed }\end{array}$ \\
\hline & I-LAST & USA & $\begin{array}{l}\text { - The Illinois Livable and Sustainable Transportation (I-LAST) was developed by: The Illinois Department of Transportation, } \\
\text { the American Consulting Engineers Council and the Illinois Road and Transportation Builders Association } \\
\text { - Categories included: 8. planning design, environmental water quality, transportation, lighting, materials, innovation } \\
\text { - Key features: strong emphasis on environmental criteria. Not a certification scheme, advisory in nature }\end{array}$ \\
\hline & INVEST & USA & $\begin{array}{l}\text { - The Infrastructure Voluntary Evaluation Sustainability Tool (INVEST) was developed by: The US Department of Transport } \\
\text { FHWA } \\
\text { - Categories included: 3. systems planning, project development, and operations and maintenance } \\
\text { - Key features: It is used as the federal highwaýs tool to encourage sustainable highway projects. It also has an extensive list } \\
\text { of criteria and a framework for stakeholder communication }{ }^{c}\end{array}$ \\
\hline & $\begin{array}{l}\text { BE }^{2} \text { ST-In- } \\
\text { Highways }^{\mathrm{TM}}\end{array}$ & USA & $\begin{array}{l}\text { - The Building Environmentally and Economically Sustainable Transportation-Infrastructure-Highways }\left(\mathrm{BE}^{2} \mathrm{ST}-\mathrm{In}-\right. \\
\text { Highways } \\
\text { University of Wisconsin } \\
\text { - Categories included: } 9 \text {. social requirements including regulation and local ordinances, greenhouse gas emission, energy } \\
\text { use, waste reduction (in/ex situ), water consumption, social carbon } \\
\text { - Key features: its main focus is to quantify the sustainability impact of using recycled materials in pavements. Restricted to } \\
\text { environmental, economic, and social issues related to quantifiable construction materials and processes }\end{array}$ \\
\hline
\end{tabular}

Note: ${ }^{a}$ Dondero, Rodgers, and Hurley (2013), ${ }^{b}$ Clark, Paulli, Tetreault, and Thomas (2009), ${ }^{c}$ Hirsch (2012), ${ }^{d}$ Lee, Edil, Benson, and Tinjum (2011). 
developed a guide to assist developing countries in integrating environmentally sustainable elements into road transportation projects. This approach was built on five national and international sustainability rating systems - see Montgomery, Schirmer, and Hirsch (2014). Another interesting example that can be mentioned is the case of Argentina, where a CEEQUAL scheme, founded by the UK Institution of Civil Engineers, has recently been applied.

Rating systems provide guidance and constitute a good basis for integrating sustainability over the whole life cycle of infrastructure projects, from planning through operation and maintenance. Actually, rating systems have helped engineering designers to set credible sustainability items related to infrastructure design. Sustainable transportation rating systems are generally understood as useful tools whereby projects are ranked and scored against their sustainability performance by putting economic, environmental, and social aspects together. They are easy to understand, simple to implement, and highly flexible and adaptable. Considering the proliferation of rating systems throughout the civil engineering field in some markets, they have been successful tools with large-scale application and acceptance into the hands of practitioners.

Given the fact that most available sustainability rating systems for infrastructure are regionally based, they incorporate the context-sensitive nature of sustainability by promoting stakeholders participation and involvement. For example, when applying the CEEQUAL system - British assessment and award scheme outside the UK, an international assessment with the local project team to adjust the weighting process for different sustainability criteria is conducted. The process ensures the importance of each criterion to be specific to the locality of the project, taking into consideration local regulations and practice of each country.

Overall, the most remarkable strength of rating systems is the holistic approach and the quantitative process defined to address sustainability. Furthermore, their philosophy is based on a good understanding of the sustainability concept. Some of them establish a clear trade-off among environmental, economic, and social aspects, while others such as Envision ${ }^{\mathrm{TM}}$ and the Infrastructure Voluntary Evaluation Sustainability Tool developed by the Federal Highway Administration (FHWA) INVEST - just put together best practices. The latter is incorporated by including some general considerations related to equity and distributional impacts.

However, strictly speaking, certification programmes also have a number of weaknesses when dealing with the concept of sustainability. First, they lack transparency and objectiveness in the definition of criteria and selection of weightings, which are not based on standardized methods of performance measurement (Lee et al., 2011). In addition "to what extent sustainability is achieved remains uncertain since consensus does not exist as to the definition of sustainability for highway and infrastructure projects" (Clevenger, Ozbek, \& Simpson, 2013, p. 7).

Second, despite the fact that they are based on similar methodological approaches with comparable categories (environment, water, energy, material, and technological and strategic innovation), the weight of the same categories across different rating systems - expressed as weights, points, or credits shows considerable levels of variation (Hirsch, 2012). Then, rating systems are not comparable enough due to their unique characteristics and focus. Each tool works as an independent performance metric, with a particular philosophy and different sustainability objectives. Even though certain flexibility seems necessary to accommodate the specific characteristics of different projects, rating systems should aspire to reach a greater consensus. 
Third, they are mostly focused on environmental issues related to construction processes and materials rather than operational phases. And fourth, despite these approaches can be implemented at the planning stage and then continue through design and construction stages, current practices, - at least in European Union countries - do not use them to assist in the decision-making process. Presently, CBA and MCDA are the most common forms of appraisal in EU member states to "make decisions" - see Bristow and Nellthorp (2000). Therefore, rating systems are not applied to conduct a comparison among different alternative designs to choose the most sustainable option.

2.3.4. Frameworks, models, and guidelines. In addition to rating systems, several models, decision support tools and frameworks have been developed to provide guidance on the appraisal of infrastructure projects - see International Federation of Consulting Engineers (2012). Since the number of tools, calculators, and guidelines available to assist practitioners is constantly growing, there is an extensive literature in parallel or in support of main appraisal tools and systems. In order to limit the present review to a manageable scope, we pay special attention to two of the most prominent transport appraisal guidelines available for decision-makers, practitioners, and public authorities in Europe: the UK Department of Transport analysis guidance - WebTAG, and (ii) the Scottish transport appraisal guidance - STAG.

Both frameworks - required for projects that need government approval - represent best practice transport appraisal guidance, providing expert advice for transport projects with regards to sustainability, and clearly establishing significant criteria for assessing options. Along with guidance on appraisal methods, they also include software tools on transport modelling — including modelling data and forecasting, variable demand models, and transport assignment models.

In summary, they are highly effective tools for identifying and quantifying sustainability impacts of transport projects and standardize the approach using detailed appraisal procedures. However, these approaches are targeted at the evaluation process rather than at the decision-making appraisal. As a consequence, the studied methodologies do not provide mechanisms for comparing all multiple trade-offs among impacts. They represent a full account of impacts, including monetized, quantified, and qualified ones, in form of "summary tables", but they do not come up with a final aggregated value for sustainability. Because of this drawback, the selection process of the most suitable alternative may be based on subjective judgements.

Finally, other two inherent weaknesses of these tools have to be mentioned. First, the social and distributional impacts continue to be based mostly on a simple qualitative approach that does not consider the aggregation of impacts over the whole life cycle of the project; and second, as recognized by the UK Department for Transport, they could benefit from restructuring since the guidance has grown large and requires rationalizing.

\subsection{Comparative Analysis of Sustainability Methods and Techniques and Limitations of Existing Research}

On the basis of the literature reviewed above, we were able to identify five sine qua non requirements for a tool to become appropriate for appraising sustainability: (i) full approach, (ii) life-cycle approach, (iii) rigorous trade-offs, (iv) transparent 
approach, and (v) adaptability to the context. We propose to compare the various techniques and methods described in the previous sections with regard to those essential requirements, to identify the five most significant research needs that should be tackled to improve the sustainability appraisal of transport infrastructure projects.

2.4.1. Requirement number 1 (full approach). Sustainability appraisal methods should analyse the widest range of impacts of a transport project including the so-called three pillars of sustainability - environmental, economic, and social criteria - including equity over generations. We borrow this idea from the "threelegged stool" of sustainability proposed by Elkington (1998), which is now consensually applied in the academic literature and the practice of public policymaking for the sustainability definition - see, for example, Dondero et al. (2013), European Commission (2006, 2009), Hueting and Reijnders (2004), White and Lee (2009). A proper tool for the sustainability assessment should include all those aspects that define fundamental principles of sustainable development.

However, despite the fact that most researchers and practitioners agrees on the need to incorporate economic, social, and environmental items to be taken into account in addressing sustainability, there is no consensus yet on what items should be measured. Regardless of the existence of a large number of checklists and guidelines to take into account all the impacts caused by transport infrastructure projects, a widely accepted and standard sustainability list of criteria against the options to be compared is lacking. On the basis of this analysis, it is possible to set the first limitation of the existing research: to clearly define a widely accepted list of sustainability items for transport infrastructure projects.

There is a need to prepare a thorough list of items to characterize sustainability. In order to make this list, it might be helpful to take advantage of the existing knowledge already provided by frameworks, guidelines, and rating systems. Creating a widely accepted list of key items requires the active involvement of governments, academics, and practitioners. The list should be especially careful to avoid overlapping among economic, social, and environmental items.

2.4.2. Requirement number 2 (life cycle approach). Authors widely acknowledge that sustainability assessments should include the whole life cycle of the project, and not just one of the stages. As explained in Section 2.2, this point was addressed by the Brundtland Commission and other academic authors (Gilmour et al., 2011; Munasinghe et al., 2001; Sijtsma, 2006; Stamford \& Azapagic, 2011). Thus, we can hardly speak of a desirable tool for appraising the sustainability of transport projects if it does not measure the impacts caused by the facility throughout its life cycle. Sustainability tools should be able not only to capture all the impacts, but also to define upstream and downstream impacts over the whole life cycle, from conception through construction, operation, maintenance, end of life processing, and final disposal.

However, this requirement is not always easy to apply to real projects. For example, in the case of roads, despite the FHWA admitting that "the sustainability characteristics of a highway or roadway project should be assessed and considered for implementation throughout its life cycle, from conception through construction, operations, and maintenance" (Federal Highway Administration, 2012); the evaluation of the sustainability of roads has focused on the construction 
process. Up to now, the application of the sustainability concept to the roadway life cycle is mostly based on energy and material employed in the project.

One possible reason justifying the difficulty of conducting a life-cycle analysis has to do with the second research need: to conduct a proper inter-temporal aggregation. One of the most important challenges for improving life-cycle evaluation is to define a standardized and accepted approach for inter-temporal aggregation of environmental, social, and economic impacts. The main reason why it is difficult to aggregate "tangible and intangible" aspects over the life span of the project is that there is no clear consensus for assessing the effect of time and future uncertainties for environmental and social aspects. Setting the right discount rate for each sustainability item is a matter that also deserves future research.

This requirement has been widely considered in the literature. Many authors have mentioned the need for additional research in the field of discounting, especially for non-market goods. For an overview of this approaches to discounting based on a different rationale for tangible and intangible effects, see, for example, Almansa and Calatrava (2007), Guo, Hepburn, Tol, and Anthoff (2006), Hepburn and Koundouri (2007), Kula and Evans (2011), Pearce, Groom, Hepburn, and Koundouri (2003), Sumaila and Walters (2005). In summary, this aggregation process is still under discussion for example, some authors suggest environmental discount rates, others apply monetary values and use traditional discount rates, while others claim for a simple aggregation even though impacts spread over a long period of time.

2.4.3. Requirement number 3 (rigorous trade-offs). When evaluating sustainability of transport projects, it is necessary to set the weights of different sustainability criteria in order to measure better their relative impact. Setting up clear tradeoffs implies understanding the extent to which the worsening of a certain sustainability item might be offset by the improving of another one. For example, in a hypothetical application of the REMBRANDT technique - see Olson, Fliedner, and Currie (1995) - to derive criteria weights for a new transport project, decision-makers have shown a strong preference for infrastructure cost savings over the positive effects on employment. This means that they assume the first criteria to be more positive for society. Consequently they strongly prefer to save money in investment, maintenance, and operating costs rather than having positive indirect effects such as changes in economic climate and labour markets due to the construction of the new project.

However, until now "decision-aiding techniques do not overcome the problem associated with incomparable quantities" (Browne \& Ryan, 2011). Despite the tension between ecological, social, and economic perspectives on sustainability, very few studies can be found in the literature addressing the issue of valuing all these attributes in the same analysis. Examples in the literature include particular studies for determining the trade-off between two specific effects such as environmental care and long-term growth - see Gradus and Smulders (1993); capital accumulation and environmental quality - see Becker (1982). Other research works include the trade-off between two specific dimensions of sustainability such as economic growth and environmental quality — see Den Butter and Verbruggen (1994) - or environmental protection versus economic development - see Feiock and Stream (2001).

Given the fact that, as far as the authors are aware, there are no previous studies that include the analysis of the relative importance of all the sustainability criteria 
in transport projects and, recognizing the importance of weighting the impacts for a rigorous and objective sustainability assessment, we propose this requirement as the third essential feature of an appropriate tool to quantify sustainable practices. Sustainability appraisal methods and techniques should use analytical and rigorous methodologies for comparing all trade-offs among economic, environmental, and social aspects.

In connection with this requirement, a third research need is now evident: to define a transparent approach for determining the relative impact of each sustainability item. For an appropriate sustainability assessment, it is necessary to determine priorities for sustainability items (called criteria weights) based on a standard, transparent, and consistent methodology. As of today there are no standardized methods for evaluating the trade-offs among economic, environmental, and social aspects in transport projects. Consequently, decision-makers fail in setting the weightings in a transparent and precise way.

This issue, found in MCDA, rating systems and models, clearly requires further analysis. In fact, it is so complex that in the most used appraisal guidelines in Europe (WebTAG and STAG) there is no weighting information provided and decision-makers must apply their own judgement when weighing the impacts to accomplish the final assessment of the transport project - see Geurs, Boon, and Van Wee (2009).

2.4.4. Requirement number 4 (adaptability to the context). In the sustainability arena, there is a need for a more objective way to evaluate projects by considering the sensitivity of the criteria in its geographical and social context. However, with few exceptions, this issue is not specifically addressed in the literature. Authors suggesting the context-sensitive nature of sustainability are those related to rating systems worldwide. As Veeravigrom et al. (2015) pointed out, many authors agree on the need to develop or adapt a rating system specifically for the context within which it will be used - see, for example, Liang (2012), Säynäjoki, Kyrö, Heinonen, and Junnila (2012), Sev (2011). Thus, these authors have acknowledged that different location and time scales may lead to different priorities.

On the basis of this assessment we have also considered that specific priorities associated with sustainable analysis may differ in different places and social conditions. Hence, for a holistic sustainability assessment of transport projects, appraisal tools should be able to address the context-sensitive nature of sustainability by identifying the particular relevance of each impact within the specific characteristics of the social and geographical context where the project is located.

Within this scenario, a major research need emerges: adapting sustainability to the context where the project is based. Sustainability appraisal tools do not have many provisions to address the specific characteristics and concerns of the society where the project is located. Most of the appraisal tools available take into consideration the same level of importance no matter the social or geographical context of the project, without considering that different regions may have very different problems and needs. For example, for a transport project to be developed in Spain the present level of unemployment is higher than the European average and its trend is relentlessly worsening. Consequently, the importance of the social sustainability item "creation of jobs" should be much higher in Spain than in other countries where unemployment is not an issue. 
To overcome this limitation, it will be necessary to evaluate sustainability items which are particularly sensitive in the geographical area and under the social circumstances where the project is located, and to identify the relevance of each sustainability item within the proposed site and surrounding area.

2.4.5. Requirement number 5 (transparent approach). Sustainability appraisal tools and methods should be transparent, rational, and formal instruments in order to minimize ambiguity - understood as the lack of clarity with regard to the methodological principles - and ensure consistency and accuracy - interpreted as the closeness of measured results to acknowledged accurate results. Hence, more rigorous the tool the better the control of systematic bias will be, and the higher its acceptability for academics and practitioners.

The research following this requirement is: to combine existing tools and methods for the sustainability appraisal of transport infrastructure projects. When dealing with sustainability of transport projects, there is hardly ever a single solution resulting from the appraisal process. Prioritizing different alternatives is a common problem because decision-making processes claim for a commonly accepted, comprehensive, and reliable appraisal method for sustainability assessment. Although a number of tools already in place have made valuable progress towards a more complete approach aimed at assessing the socio-economic and environmental feasibility of these projects, they lack a more integrated, consistent, and systematic approach to be applied.

2.4.6. How do existing tools comply with these requirements? As none of the tools and methods already analysed are suitable for a holistic assessment of the sustainability of a transport projects, further research is recommended to explore existing tools in order to use them more effectively for sustainability appraisal.

Table 3 gives a qualitative comparison of the different methods analysed on the basis of the literature review described above. We included tools which are restricted to a single criterion (economic/environmental or social) that is, CBA, LCA, and SLCA, as well as those with a multiple approach, that is, MCDA, rating systems, models, and frameworks. Each column describes to what extent the five requirements previously explained are met by each method. In order to facilitate the interpretation of the analysis, we set an assessment "score" that follows these principles: " $\sqrt{ }$ " for a requirement which is covered by the sustainability appraisal tool (SAT), " $\approx \sqrt{ }$ " for a requirement which is partially taken into account by the SAT, and " $\boldsymbol{\chi}$ " for a requirement which is not covered at all by the SAT. The scoring comes from a consensus of the authors of this paper made after a careful review of the scientific and practice literature - some references supporting our analysis are shown in brackets - as well as from our knowledge of the different methodologies. In any case, it does not constitute an absolute assignment, but serves as a reference from what is considered acceptable for the appropriate appraising sustainability.

The main results coming out of Table 3 is that despite the numerous sustainability tools available, none of them seems to be useful for appraising sustainability in a thorough way. While there are positive characteristics associated with each tool, some practical issues remain unsolved. The tools analysed in this research did not succeed in fulfilling all the requirements cited above. Table 3 also highlights that methods may show complementary features: for example, some of them have problems with non-economic values, whereas others enable incorporating other 
Table 3. Qualitative comparison of methods and tools for sustainability assessment of transport infrastructure projects

\begin{tabular}{|c|c|c|c|c|c|c|}
\hline Tool & & 1. Full approach & 2. Life-cycle approach & 3.Rigorous trade-offs & $\begin{array}{l}\text { 4.Transparent } \\
\text { approach }\end{array}$ & $\begin{array}{l}\text { 5.Adaptability to the } \\
\text { context }\end{array}$ \\
\hline \multirow[t]{2}{*}{$\begin{array}{l}\text { Project appraisal } \\
\text { methods }\end{array}$} & CBA & $\begin{array}{l}\approx \sqrt{ } \\
\text { Problems with non- } \\
\text { economic values }^{\mathrm{a}} \text {. } \\
\text { Assessing equity has } \\
\text { certain limitations }^{\mathrm{b}}\end{array}$ & $\begin{array}{l}\approx \sqrt{ } \\
\text { In practice, limited } \\
\text { considerations } \\
\text { regarding the full life } \\
\text { cycle (e.g. end of life of } \\
\text { materials are rarely } \\
\text { included) }\end{array}$ & $\begin{array}{l}\approx \sqrt{ } \\
\text { Well-known } \\
\text { limitations when } \\
\text { converting all values } \\
\text { into monetary terms }\end{array}$ & $\begin{array}{l}\sqrt{ } \\
\text { In general rigorous, } \\
\text { transparent, and } \\
\text { formal }{ }^{\mathrm{d}} \text {, but } \\
\text { assumptions hidden } \\
\text { behind a single result }^{\mathrm{e}}\end{array}$ & $\begin{array}{l}\approx \sqrt{ } \\
\text { Values for economic objects } \\
\text { are context sensitive. } \\
\text { Context is also incorporated } \\
\text { through the discount rate. } \\
\text { There has been and still is } \\
\text { considerable debate about } \\
\text { it }^{\mathrm{f}} \text {. }\end{array}$ \\
\hline & MCDA & $\begin{array}{l}\sqrt{ } \\
\text { Allows to incorporate } \\
\text { other aspects apart from } \\
\text { the economic ones. } \\
\text { Several criteria can be } \\
\text { taken into account } \\
\text { simultaneously }\end{array}$ & $\begin{array}{l}\approx \sqrt{ } \\
\text { Strive to have a life- } \\
\text { cycle focus but in } \\
\text { practice this objective is } \\
\text { not always reached }\end{array}$ & $\begin{array}{l}\approx \sqrt{ } \\
\text { Involves a certain } \\
\text { element of } \\
\text { subjectiveness }{ }^{\mathrm{g}, \mathrm{d}}\end{array}$ & $\begin{array}{l}\approx \sqrt{ } \\
\text { Criteria weighting } \\
\text { may be subjective: } \\
\text { black-box́ concept }\end{array}$ & $\begin{array}{l}\approx \sqrt{ } \\
\text { Usually incorporated } \\
\text { through decision-makers' } \\
\text { judgements. In practice, this } \\
\text { process may be highly } \\
\text { questionable }\end{array}$ \\
\hline \multirow[t]{2}{*}{$\begin{array}{l}\text { Environmental/ } \\
\text { social } \\
\text { assessment } \\
\text { methods }\end{array}$} & LCA & $\begin{array}{l}\boldsymbol{\chi} \\
\text { Social and economic } \\
\text { aspects are not taken into } \\
\text { account in LCA study }{ }^{\mathrm{h}, \mathrm{i}} .\end{array}$ & $\begin{array}{l}\sqrt{ } \\
\text { Used to quantify } \\
\text { environmental impacts } \\
\text { and resource } \\
\text { consumption during } \\
\text { the entire life cycle }{ }^{\mathrm{j}} \text {. }\end{array}$ & $\begin{array}{l}\boldsymbol{\chi} \\
\text { It Does not consider } \\
\text { economic and social } \\
\text { aspects }\end{array}$ & $\begin{array}{l}\sqrt{ } \\
\text { Although it is a } \\
\text { standardized tool, } \\
\text { still needs } \\
\text { improvements to } \\
\text { increase its accuracy }{ }^{\mathrm{k}}\end{array}$ & $\begin{array}{l}\chi \\
\text { Included interactions } \\
\text { between activity and the } \\
\text { surrounding environment } \\
\text { but not the context- } \\
\text { sensitive nature of } \\
\text { sustainability }\end{array}$ \\
\hline & SLCA & $\begin{array}{l}\boldsymbol{X} \\
\text { Economic and } \\
\text { environmental impacts } \\
\text { are not included within } \\
\text { its scope }\end{array}$ & $\begin{array}{l}\approx \sqrt{ } \\
\text { It may potentially } \\
\text { include social impacts } \\
\text { in all stages for its life } \\
\text { cycle }^{1}\end{array}$ & $\begin{array}{l}\chi \\
\text { It Does not consider } \\
\text { economic and } \\
\text { environmental } \\
\text { aspects. }\end{array}$ & $\begin{array}{l}\approx \sqrt{ } \\
\text { Short history, a } \\
\text { number of } \\
\text { fundamental issues } \\
\text { have not been agreed } \\
\text { on and resolved }\end{array}$ & $\begin{array}{l}\chi \\
\text { Efforts will have to be made } \\
\text { to adopt the context when } \\
\text { defining indicators }{ }^{\mathrm{n}} \text {. }\end{array}$ \\
\hline
\end{tabular}


Sustainability

assessment

methodologies

\section{Rating}

systems

Frameworks $^{\mathrm{q}}$
The triple bottom line is included but in practice they are mostly focused on environmental issues and on the construction stage. In theory, they consider the full life cycle of projects ${ }^{\circ}$$$
\sqrt{ }
$$

High-level assessment of

social, economic, and

environmental aspects

$$
\approx \sqrt{ }
$$

The project life cycle is not fully considered for items such as the social ones $\approx \sqrt{ }$

They lack transparency and objectiveness in

the selection of criteria and weighting process $^{\mathrm{p}}$.

\section{$x$}

Not applicable, they

do not aggregate

results into a single

value. may be subjective. $\approx \sqrt{ }$

Thought as an instrument

for a specific context, and

that limits its applicability

to other contexts

$\approx \sqrt{ }$

Reliable and accurate Thought as frameworks for tools, but the selection a specific context, and that of the best alternative limits their applicability to

other contexts

Note: " $\sqrt{ }$ ": this requirement is completely covered by the SAT; “ $\approx \sqrt{ }$ " : this requirement is partially taken into account by the SAT; " $\chi$ ": this requirement is not covered by the SAT.

${ }^{a}$ Omura (2004); ${ }^{\mathrm{b}}$ Thomopoulos, Grant-Muller, and Tight (2009); ${ }^{\mathrm{C} B e r i a, ~ M a l t e s e, ~ a n d ~ M a r i o t t i ~(2011) ; ~}{ }^{\mathrm{d}}$ Beria et al. (2011); ${ }^{\mathrm{B} B r o w n e}$ and Ryan (2011); ${ }^{\mathrm{f}}$ Sijtsma (2006); ${ }^{\mathrm{g}}$ Barfod

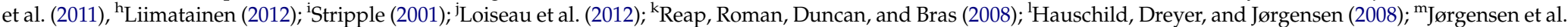
(2008); ${ }^{\mathrm{n}}$ Grießhammer et al. (2006); ${ }^{\mathrm{o}}$ Reid, Davis, and Bevan (2012); ${ }^{\mathrm{p}}$ Lee et al. (2011). ${ }^{\mathrm{q}}$ Frameworks included in this table refer to those described above. 
aspects apart from the economic ones. As a result, we conclude that an integration of current tools with complementary attributes could be beneficial for effectively handling sustainability in the ex ante appraisal of project alternatives.

\section{Conclusions and New Ideas to Improve Sustainability Appraisal}

The literature review conducted in the previous sections shows that, although the concept of sustainability has gained increasing importance, the comprehensive sustainability appraisal of transport infrastructure projects is still an unresolved matter. In this review, we found that none of the existing tools includes the necessary requirements to be appropriate for appraising sustainability of transport projects: for example, to integrate the widest possible range of impacts compliant to a life-cycle approach, to provide a rigorous method to analyse the balance among the "triple bottom line" aspects, and to include the context-sensitive nature of sustainability. Consequently, despite the fact that the current approaches offer some value for sustainability assessment, none of them can be used to carry out a holistic appraisal. However, we point out that among the existing tools, the MCDA approach seems to be the most suitable technique because of its flexibility to incorporate sustainability drivers.

Taking into account that finding an optimal tool to appraise sustainability of transport projects is a complicated issue, and being aware that a compromise is necessary between accurateness and workability, we can propose some ideas to improve sustainability appraisal. Taking advantage of the complementary relationship found among current tools - see Table 3 - we propose a combination of the MCDA with other tools for a more complete sustainability assessment of transport projects.

As the first approach, we suggest integrating the multiple criteria approach methodology with the single criterion approach (composite tool) in order to keep the strengths of each appraisal method. Based on the assumption that MCDA and CBA can be used in tandem, it will be appropriate to seek a solution for expressing the CBA results into the same language as the MCDA results. Composite decision support models - based on combining methodologies for economic, environmental, and social assessment - are lacking in the state of the art. Despite the fact that recent studies have tried to combine these methodologies - see Barfod et al. (2011), Gühnemann et al. (2012), Sijtsma (2006) — in practice "effective implementation has proven elusive" (Gühnemann et al., 2012). The "combined tool" should be able to take into account several criteria simultaneously — including those difficult to quantify — with a life-cycle focus. In addition, this composite tool should be rigorous, transparent, and formal, and will incorporate the context-sensitive nature of sustainability in the analysis.

From the attempt to combine the strengths of the current appraisal methods to address sustainability, special attention should be given to two specific aspects: (i) the inter-temporal aggregation of environmental, social, and economic impacts to improve the life-cycle evaluation and (ii) the process of setting the weights of each sustainability criterion. A potential approach to tackle the first problem may include alternative discounting methods according to the characteristics of the specific sustainability criteria: for example, those that can be quantified and monetized with market prices; those that can be quantified and are not bought and sold in the market; and those that cannot be quantified. On the other hand, a potential approach for increasing the rigour and objectivity in the setting of the 
weights of the MCDA may consist of incorporating the sensitivity of each criterion to the social and geographical context where the project is situated, and setting the trade-offs among different criteria from consensus-based comparative judgements and preferences.

\section{Disclosure statement}

No potential conflict of interest was reported by the authors.

\section{Funding}

This work was supported by the European Investment Bank under The STAREBEI programme. The findings, interpretations, and conclusions presented in this article are entirely those of the authors and should not be attributed in any manner to the European Investment Bank. The authors wish to thank the Spanish Ministry of Economy and Competitiveness, which has funded the SUPPORT Project - EU support mechanisms to promote public-private partnerships for financing TRANSEUROPEAN TRANSPORT INFRASTRUCTURE - [TRA2012-36590]. Period: 1 January 2013-31 December 2016.

\section{Notes}

1. Sustainability criteria are defined as the basic fundamentals or principles used to judge the sustainability of transport projects and to compare the alternatives. They can be grouped into different sustainability components (economic/social/environmental).

\section{References}

Almansa, C., \& Calatrava, J. (2007). Reconciling sustainability and discounting in cost-benefit analysis: A methodological proposal. Ecological Economics, 60(4), 712-725. doi:10.1016/j.ecolecon.2006.05.002

Anderson, J. L., \& Muench, S. T. (2013). Sustainability trends measured by the greenroads rating system. Transportation Research Record: Journal of the Transportation Research Board, 2357(206), 24-32. doi:10.3141/2357-03

Baker, J. W., \& Lepech, M. D. (2009, September). Treatment of uncertainties in life cycle assessment. Paper presented at The 10th International Conference on Structural Safety and Reliability (ICOSSAR09), Osaka.

Barfod, M. B., Salling, K. B., \& Leleur, S. (2011). Composite decision support by combining cost-benefit and multi-criteria decision analysis. Decision Support Systems, 51(1), 167-175. doi:10.1016/j.dss.2010. 12.005

Becker, R. A. (1982, June). Intergenerational equity: The capital-environment trade-off. Journal of Environmental Economics and Management, 9(2), 165-185. doi:10.1016/0095-0696(82)90020-1

Beria, P., Maltese, I., \& Mariotti, I. (2011, June). Comparing cost benefit and multi-criteria analysis?: The evaluation of neighbourhoodś sustainable mobility. Paper presented at the XIII Riunione Scientifica Della Società Italiana Degli Economisti Dei Trasporti E Della Logistica (SIET), Messina.

Bristow, A. L., \& Nellthorp, J. (2000). Transport project appraisal in the European Union. Transport Policy, 7(1), 51-60. doi:10.1016/S0967-070X(00)00010-X

Browne, D., \& Ryan, L. (2011). Comparative analysis of evaluation techniques for transport policies. Environmental Impact Assessment Review, 31(3), 226-233. doi:10.1016/j.eiar.2010.11.001

Brundtland World Commission on Environment and Development. (1987). Report of the world commission on environment and development. Retrieved from http://www.un.org/documents/ga/res/42/ ares42-187.htm

Chaharbaghi, K., \& Willis, R. (1999). The study and practice of sustainable development. Engineering Management Journal, 9(1), 41-48. Retrieved from http://digital-library.theiet.org/content/ journals/10.1049/em_19990115

Cheng, E. W. L., \& Li, H. (2005). Analytic network process applied to project selection. Journal of Construction Engineering and Management, 131(4), 459-466. doi:10.1061/(ASCE)0733-9364(2005)131:4(459) 
Ciegis, R., Ramanauskiene, J., \& Martinkus, B. (2009). The concept of sustainable development and its use for sustainability Scenarios. Inzinerine Ekonomika-Engineering Economics, 2(62), 28-37. Retrieved from http:/ / www.ktu.edu/lt/mokslas/zurnalai/inzeko/62/1392-2758-2009-2-62-28.pdf

Clark, M., Paulli, C., Tetreault, Z., \& Thomas, J. (2009). Green guide for roads rating system. Worcester: Published reports of the Worcester Polytechnical Institute. Retrieved from http://www.wpi.edu/ Images/CMS/CEE/Green_Guide_for_Roads_Rating_System.pdf

Clevenger, C. M., Ozbek, M. E., \& Simpson, S. (2013, April). Review of sustainability rating systems used for infrastructure projects. Paper presented a The 49th ASC Annual International Conference Proceedings, San Luis Obispo, CA.

Cundrič, A., Kern, T., \& Rajkovič, V. (2008). A qualitative model for road investment appraisal. Transport Policy, 15(4), 1-18. doi:10.1016/j.tranpol.2008.05.003.A

Dasgupta, S., \& Tam, E. K. (2005). Indicators and framework for assessing sustainable infrastructure. Canadian Journal of Civil Engineering, 32(1), 30-44. doi:10.1139/104-101

Den Butter, F. A. G., \& Verbruggen, H. (1994). Measuring the trade-off between economic growth and a clean environment. Environmental E Resource Economics, 4(2), 187-208. doi:10.1007/BF00692203

Dennison, F., Azapagic, A., Clift, R., \& Colbourne, J. (1998). Assessing management options for wastewater treatment works in the context of life cycle assessment. Water Science and Technology, 38(11), 2330. doi:10.1016/S0273-1223(98)00636-2

Dondero, G., Rodgers, K., \& Hurley, P. T. (2013, January). Developing a comprehensive sustainable transportation analysis framework. Paper presented at The 92nd Annual Meeting of the Transportation Research Board, Washingtong, DC.

Elkington, J. (1998). Cannibals with forks: The triple bottom line of 21st century. New Society. doi:http:/ / doi. wiley.com/10.1002/tqem.3310080106

European Commission. (2006). Handbook for trade sustainability impact assessment. Published reports of the European Commission. Retrieved from http://trade.ec.europa.eu/doclib/docs/2006/march/ tradoc_127974.pdf

European Commission. (2009). Impact assessment guidelines. Published reports of the European Commission. Retrieved from http:/ / ec.europa.eu/smart-regulation/impact/commission_guidelines/docs / iag_2009_en.pdf

Federal Highway Administration. (2012). INVEST sustainable highways self-evaluation tool. Published reports of the Federal Highway Administration. Retrieved from https://www. sustainablehighways.org/INVEST_1.0_Compendium_Web.pdf

Feiock, R. C., \& Stream, C. (2001). Environmental protection versus economic development: A false trade-off? Public Administration Review, 61(3), 313-321. doi:10.1111/0033-3352.00032

Friesz, T. L., Tourreilles, F. A., Han, A.-W., \& Fernandez, J. E. (1980). Comparison of multicriteria optimization methods in transport project evaluation. Transportation Research Record, (751), 38-41. Retrieved from http://worldcat.org/issn/03611981

Frohwein, H. I., Lambert, J. H., Haimes, Y. Y., \& Schiff, L. A. (1999). Multicriteria framework to aid comparison of roadway improvement projects. Journal of Transportation Engineering, 125(3), 224-230. doi:10.1061/(ASCE)0733-947X(1999)125:3(224)

Gambatese, J. A., \& Rajendran, S. (2005, April). Sustainable roadway construction: Energy consumption and material waste generation of roadways. Paper presented at the Construction Research Congress 2005 of the American Society of Civil Engineers, San Diego, CA.

George, C. (2001). Sustainability appraisal for sustainable development: Integrating everything from jobs to climate change. Impact Assessment and Project Appraisal, 19(2), 95-106. doi:10.3152/ 147154601781767104

Geurs, K. T., Boon, W., \& Van Wee, B. (2009). Social impacts of transport: Literature review and the state of the practice of transport appraisal in the Netherlands and the United Kingdom. Transport Reviews, 29(1), 69-90. doi:10.1080/01441640802130490

Gilmour, D., Blackwood, D., Banks, L., \& Wilson, F. (2011). Sustainable development indicators for major infrastructure projects. Proceedings of the Institution of Civil Engineers-Municipal Engineer, 164(1), 15-24. doi:10.1680muen.800020

Giuliano, G. (1985). A multicriteria method for transportation investment planning. Transportation Research Part A: General, 19(1), 29-41. doi:10.1016/0191-2607(85)90004-4

Gradus, R., \& Smulders, S. (1993). The trade-off between environmental care and long-term growth-Pollution in three prototype growth models. Journal of Economics, 58(1), 25-51. doi:10.1007/BF01234800

Grant-Muller, S. M., Mackie, P., Nellthorp, J., \& Pearman, A. (2001). Economic appraisal of European transport projects: The state-of-the-art revisited. Transport Reviews, 21, 237-261. doi:10.1080/ 01441640119423 
Grießhammer, R., Benoît, C., Dreyer, L. C., Flysjö, A., Mazijn, B., Méthot, A., \& Weidema, B. (2006). Feasibility study?: Integration of social aspects into LCA. Retrieved from http://www.saiplatform. org/uploads/Library/UNEP-SETACLifeCycleInitiativeTFonSocialIssues-FeasibilityStudy.pdf

Gühnemann, A., Laird, J. J., \& Pearman, A. D. (2012). Combining cost-benefit and multi-criteria analysis to prioritise a national road infrastructure programme. Transport Policy, 23, 15-24. doi:10.1016/j. tranpol.2012.05.005

Guo, J., Hepburn, C. J., Tol, R. S. J., \& Anthoff, D. (2006). Discounting and the social cost of carbon: A closer look at uncertainty. Environmental Science and Policy, 9, 205-216. doi:10.1016/j.envsci.2005.11. 010

Hauschild, M. Z., Dreyer, L. C., \& Jørgensen, A. (2008). Assessing social impacts in a life cycle perspective - Lessons learned. CIRP Annals-Manufacturing Technology, 57, 21-24. doi:10.1016/j.cirp.2008.03. 002

Hepburn, C. J., \& Koundouri, P. (2007). Recent advances in discounting: Implications for forest economics. Journal of Forest Economics, 13, 169-189. doi:10.1016/j.jfe.2007.02.008

Hirsch, A. (2012, January). Overview of sustainability rating system trends in transportation. Paper presented at The 92nd annual meeting of the Transportation Research Board, Washington DC. Retrieved from http:/ / terralogicss.com/resources.htm

Hobbs, B. F., \& Horn, G. T. (1997). Building public confidence in energy planning: A multimethod MCDM approach to demand-side planning at BC gas. Energy Policy, 25(3), 357-375. doi:10.1016/ S0301-4215(97)00025-6

Huang, I. B., Keisler, J., \& Linkov, I. (2011). Multi-criteria decision analysis in environmental sciences: Ten years of applications and trends. Science of the Total Environment, 409(19), 3578-3594. doi:10.1016/ j.scitotenv.2011.06.022

Hueting, R., \& Reijnders, L. (2004). Broad sustainability contra sustainability: The proper construction of sustainability indicators. Ecological Economics, 50(3-4), 249-260. doi:10.1016/j.ecolecon.2004.03. 031

Hyard, A. (2012). Cost-benefit analysis according to Sen: An application in the evaluation of transport infrastructures in France. Transportation Research Part A: Policy and Practice, 46(4), 707-719. doi:10. 1016/j.tra.2012.01.002

Iniestra, J. G., \& Gutiérrez, J. G. (2009). Multicriteria decisions on interdependent infrastructure transportation projects using an evolutionary-based framework. Applied Soft Computing, 9(2), 512-526. doi:10.1016/j.asoc.2008.07.006

InterAmerican Development Bank. (2015, January). Adapting U.S. sustainability tool for roadway project in South America. Paper presented at the 94th annual meeting of the Transportation Research Board, Washington, DC. Retrieved from http://amonline.trb.org/trb57535-2015-1.1793793/t008-1. 1817812/829-1.1803401/p15-5785-1.1817843/p15-5785-1.1817844?login_formerror=auth\&qr=1

International Federation of Consulting Engineers. (2012). State of the world report 2012. Sustainable infrastructure. Published reports of the International Federation of national Member Associations of consulting engineers (FIDIC). Retrieved from http://fidic.org/books/state-world-report-2012sustainable-infrastructure

Janic, M. (2003). Multicriteria evaluation of high-speed Rail, Transrapid maglevand air passenger transport in Europe. Transportation Planning and Technology, 26(6), 491-512. doi:10.1080/0308106032000167373

Jones, H., Moura, F., \& Domingos, T. (2014). Transport infrastructure project evaluation using cost-benefit analysis. Procedia-Social and Behavioral Sciences, 111, 400-409. doi:10.1016/j.sbspro.2014.01.073

Jørgensen, A., Le Bocq, A., Nazarkina, L., \& Hauschild, M. (2008). Methodologies for social life cycle assessment. The International Journal of Life Cycle Assessment, 13(2), 96-103. doi:10.1065/lca2007.11.367

Kabir, G., Sadiq, R., \& Tesfamariam, S. (2013). A review of multi-criteria decision-making methods for infrastructure management. Structure and Infrastructure Engineering, 10, 1176-1210. doi:10.1080/ 15732479.2013.795978

Keoleian, G. A., \& Spitzley, D. V. (2006). Life cycle based sustainability metrics. In Sustainability science and engineering: Defining principles (pp. 127-159). Amsterdam: Elsevier B.V.

Khorramshahgol, R., \& Steiner, H. (1988). Resource analysis in project evaluation: A multicriteria approach. Journal of the Operational Research Society, 39(9), 795-803. Retrieved from http://www. jstor.org/stable/10.2307/2583522

Kowalski, K., Stagl, S., Madlener, R., \& Omann, I. (2009). Sustainable energy futures: Methodological challenges in combining scenarios and participatory multi-criteria analysis. European Journal of Operational Research, 197(3), 1063-1074. doi:10.1016/j.ejor.2007.12.049

Kula, E., \& Evans, D. (2011). Dual discounting in cost-benefit analysis for environmental impacts. Environmental Impact Assessment Review, 31(3), 180-186. doi:10.1016/j.eiar.2010.06.001 
Lee, J., Edil, T., Benson, C., \& Tinjum, J. (2011, January). Evaluation of variable affecting sustainable highway design using the Be2st-in-HighwaysTM system. Paper presented at the 90th annual meeting of the Transportation Research Board, Washington, DC.

Lester, E., \& Olmsted, S. (2015, January). The collaborative benefits of using FHWA's INVEST-A state department of transportation sustainability implementation case study. Paper presented at The 94th Annual Meeting of the Transportation Research Board, Washington, DC.

Liang, S. (2012, June). International experiences on sustainable scoring system: Comparisons and applications. Paper presented at The 6th International Association for China Planning Conference, Wuhan.

Liimatainen, V. (2012). Life cycle assessment guideline for protection relay?: 615 series. Retrieved from http://www.theseus.fi/handle/10024/43465

Loiseau, E., Junqua, G., Roux, P., \& Bellon-Maurel, V. (2012). Environmental assessment of a territory: An overview of existing tools and methods. Journal of Environmental Management, 112, 213-25. doi:10. 1016/j.jenvman.2012.07.024

Mackie, P., \& Preston, J. (1998). Twenty-one sources of error and bias in transport project appraisal. Transport Policy, 5(1), 1-7. doi:10.1016/S0967-070X(98)00004-3

Mandell, S. (2013). Carbon emissions and cost benefit analyses (Working Paper No. 2013-32). Sweden: International Transport Forum.

Matsuhashi, R., Hikita, K., \& Ishitani, H. (1996). Model analyses for sustainable energy supply taking resource and environmental constraints into consideration. Energy Conversion and Management, 37(6), 1253-1258. doi:10.1016/0196-8904(95)00329-0

Montgomery, R., Schirmer, H., Hirsch, A. (2014). A sustainability rating system for roads in developing countries. Bridges, 10, 1086-1096. doi: 10.1061/9780784478745.103

Muench, S. T., Armstrong, A., \& Allen, B. (2012). Sustainable roadway design and construction in federal lands highway program. Transportation Research Record: Journal of the Transportation Research Board, 2271(-1), 19-30. doi:10.3141/2271-03

Munasinghe, M., Sunkel, O., \& Miguel, C. D. (2001). The sustainability of long-term growth: Socioeconomic and ecological perspectives. Edward Elgar Publishing Ltd. Retrieved from http:/ /www.cabdirect.org/ abstracts / 20023109930.html

Munda, G. (1995). Multicriteria evaluation in a fuzzy environment: Theory and applications in ecological economics. Physica-Verlag. Retrieved from http://www.cabdirect.org/abstracts/19961806871.html

Munda, G. (2004). Social multi-criteria evaluation: Methodological foundations and operational consequences. European Journal of Operational Research, 158(3), 662-677. doi:10.1016/S0377-2217(03)00369-2

Munda, G., Nijkamp, P., \& Rietveld, P. (1998). Sustainable development: Concepts, rationalities and strategies. Dordrecht: Springer Netherlands. doi:10.1007/978-94-017-3188-1

National Cooperative Highway Research Program-NCHRP. (2011). A guidebook for sustainability performance measurement for transportation agencies (Report 708). Washington, DC. Published reports of the National Cooperative Highway Research Program. Retrieved from http://www.trb.org/ Publications/Blurbs/166313.aspx

Niemeyer, S., \& Spash, C. L. (2001). Environmental valuation analysis, public deliberation, and their pragmatic syntheses: A critical appraisal. Environment and Planning C: Government and Policy, 19(4), 567-585. doi:10.1068/c9s

Olson, D. L., Fliedner, G., \& Currie, K. (1995). Comparison of the REMBRANDT system with analytic hierarchy process. European Journal of Operational Research, 82(3), 522-539. doi:10.1016/03772217(93)E0340-4

Omura, M. (2004). Cost-Benefit analysis revisited: Is it a useful tool for sustainable development? Kobe University Economic Review, 50, 43-58. Retrieved from http://www.lib.kobe-u.ac.jp/repository/00399714.pdf

Ophus, E., \& Digernes, V. (1996). Life-cycle assessment of an alkyd emulsion?: Improvements in environmental performance. Surface Coatings International, 79(4), 155-176. Retrieved from http:// cat.inist.fr $/$ ?aModele $=$ afficheN\&cpsidt $=3076576$

Parkin, S. (2000). Contexts and drivers for operationalizing sustainable development. Proceedings of the Institution of Civil Engineers-Civil Engineering, 138(6), 9-15. doi:10.1680/cien.2000.138.6.9

Parkin, S., Sommer, F., \& Uren, S. (2003). Sustainable development: Understanding the concept and practical challenge*. Proceedings of the Institution of Civil Engineers-Engineering Sustainability, 156(1), 19-26. doi:10.1680/ensu.2003.156.1.19

Paul, B. D. (2008). A history of the concept of sustainable development: Literature review. The Annals of the University of Oradea, Economic Science Series, 17(2), 576-580. Retrieved from http://steconomice. uoradea.ro/anale/volume/2008/v2-economy-and-business-administration/101.pdf

Pearce, D., Groom, B., Hepburn, C., \& Koundouri, P. (2003). Valuing the future: Recent advances in social discounting. World Economics, 4(2), 121-141. doi:10.1.1.121.130 
Pearce, D., \& Nash, C. (1981). The social appraisal of projects-a text in cost-benefit-analysis. London: Macmillan. Retrieved from <Go to ISI $>$ :/ / A1982NP40600029

Radermacher, W. (1999). Indicators, green accounting and environment statistics — information requirements for sustainable development. International Statistical Review, 67(3), 339-354. doi:10. 1111/j.1751-5823.1999.tb00453.x

Raluy, R. G., Serra, L., \& Uche, J. (2005). Life cycle assessment of desalination technologies integrated with renewable energies. Desalination, 183(1), 81-93. doi:10.1016/j.desal.2005.04.023

Reap, J., Roman, F., Duncan, S., \& Bras, B. (2008). A survey of unresolved problems in life cycle assessment. The International Journal of Life Cycle Assessment, 13(5), 374-388. doi:10.1007/s11367-008-0009-9

Reed, R., Bilos, A., \& Wilkinson, S. (2009). International comparison of sustainable rating tools. Journal of Sustainable Real Estate, 1(1), 1-22. Retrieved from http://www.costar.com/josre/JournalPdfs/01Sustainable-Rating-Tools.pdf

Reid, L., Davis, A., \& Bevan, T. (2012, January). An approach for integrating sustainability into roadway project development. Paper presented at The 92nd annual meeting of the Transportation Research Board, Washington, DC.

Samberg, S., Bassok, A., \& Holman, S. (2012). Method for evaluation of sustainable transportation. Transportation Research Record: Journal of the Transportation Research Board, 2242, 1-8. doi:10.3141/ 2242-01

Sayers, T. M., Jessop, A. T., \& Hills, P. J. (2003). Multi-criteria evaluation of transport options - flexible, transparent and user-friendly? Transport Policy, 10(2), 95-105. doi:10.1016/S0967-070X(02)00049-5

Säynäjoki, E., Kyrö, R., Heinonen, J., \& Junnila, S. (2012). An assessment of the applicability of three international neighbourhood sustainability rating systems to diverse local conditions, with a focus on Nordic case areas. International Journal of Sustainable Building Technology and Urban Development, 3(2), 96-104. doi:10.1080/2093761X.2012.696319

Sev, A. (2011). A comparative analysis of building environmental assessment tools and suggestions for regional adaptations. Civil Engineering and Environmental Systems, 28, 231-245. doi:10.1080/10286608. 2011.588327

Shelbourn, M. A., Bouchlaghem, D. M., Anumba, C. J., Carillo, P. M., Khalfan, M. M., \& Glass, J. (2006). Managing knowledge in the context of sustainable construction. ITcon, 11, 57-71. Retrieved from http://itcon.org/data/works/att/2006_4.content.07629.pdf

Sijtsma, F. J. (2006). Project evaluation, sustainability and accountability: Combining cost-benefit analysis $(C B A)$ and multi-criteria analysis (MCA) (Doctoral dissertation). University of Groningen. Retrieved from http://www.waddenacademie.nl/fileadmin/inhoud/pdf/06-wadweten/Proefschriften/Thesis_ Sytsma.pdf

Simpson, S. P., Clevenger, C. M., Ozbek, M. E., Kohlman, E. R., \& Atadero, R. (2014, January). A framework for assessing transportation sustainability rating systems for implementation in U.S. State departments of transportation. Paper presented at the 93rd annual meeting of the Transportation Research Board, Washington, DC.

Stamford, L., \& Azapagic, A. (2011). Sustainability indicators for the assessment of nuclear power. Energy, 36(10), 6037-6057. doi:10.1016/j.energy.2011.08.011

Stripple, H. (2001). Life cycle assessment of road: A pilot study for inventory analysis. (Report 96). Sweden: Swedish Environmental Research Institute.

Stripple, H., \& Erlandsson, M. (2004). Methods and possibilities for application of life cycle assessment in strategic environmental assessment of transport infrastructures (Report B1661). Stockholm: Swedish Environmental Research Institute.

Sturgill, R. E., Van Dyke, C., McCormack, S., \& Kreis, S. D. (2015, January). Case analysis of inherent programmatic sustainability resulting from application of context sensitive design principles. Paper presented at The 94th annual meeting of the Transportation Research Board, Washington, DC.

Sumaila, U. R., \& Walters, C. (2005). Intergenerational discounting: A new intuitive approach. Ecological Economics, 52, 135-142. doi:10.1016/j.ecolecon.2003.11.012

Tahara, K., Kojima, T., \& Inaba, A. (1997). Evaluation of CO2 payback time of power plants by LCA. Energy Conversion and Management, 38, S615-S620. doi:10.1016/S0196-8904(97)00005-8

TEP and CEPS. (2010). Study on social impact assessment as a tool for mainstreaming social inclusion and social protection concerns in public policy in EU Member States. London: Published reports of the European Commission. Retrieved from http://www.trb.org/Publications/Blurbs/166313.aspx Retrieved from http://csdle.lex.unict.it/docs/labourweb/Study-on-Social-Impact-Assessment-asa-tool-for-mainstreaming-social-inclusion-and-social-protection/2459.aspx 
Thomopoulos, N., Grant-Muller, S., \& Tight, M. R. (2009). Incorporating equity considerations in transport infrastructure evaluation: Current practice and a proposed methodology. Evaluation and Program Planning, 32(4), 351-359. doi:10.1016/j.evalprogplan.2009.06.013

Treloar, G. J., Love, P. E., \& Crawford, R. H. (2004). Hybrid life-cycle inventory for road construction and use. Journal of Construction Engineering and Management, 130(1), 43-49. doi:10.1061/(ASCE)07339364(2004)130:1(43)

Tsai, C. Y., \& Chang, A. S. (2012). Framework for developing construction sustainability items: The example of highway design. Journal of Cleaner Production, 20(1), 127-136. doi:10.1016/j.jclepro. 2011.08.009

Tudela, A., Akiki, N., \& Cisternas, R. (2006). Comparing the output of cost benefit and multi-criteria analysis. Transportation Research Part A: Policy and Practice, 40(5), 414-423. doi:10.1016/j.tra.2005.08. 002

Ugwu, O. O., Kumaraswamy, M. M., Wong, A., \& Ng, S. T. (2006). Sustainability appraisal in infrastructure projects (SUSAIP): Part 2: A case study in bridge design. Automation in Construction, 15(2), 229238. doi:10.1016/j.autcon.2005.05.005

Van Wee, B. (2007). Rail infrastructure: Challenges for cost-benefit analysis and other ex ante Evaluations. Transportation Planning and Technology, 30(1), 31-48. doi:10.1080/03081060701207995

Veeravigrom, M., Muench, S. T., \& Kosonen, H. (2015, January). A global framework for sustainable roadway rating system. Paper presented at The 94th annual meeting of the Transportation Research Board, Washington, DC.

Vickerman, R. (2007). Cost-benefit analysis and large-scale infrastructure projects: State of the art and challenges. Environment and Planning B: Planning and Design, 34(4), 598-610. doi:10.1068/b32112

Walker, G. (2010). Environmental justice, impact assessment and the politics of knowledge: The implications of assessing the social distribution of environmental outcomes. Environmental Impact Assessment Review, 30(5), 312-318. Retrieved from http:/ /www.scopus.com/inward/record.url?eid=2-s2. 0-77955279502\&partnerID $=40 \& m d 5=0 d 2 b 63 e 45841482 \mathrm{e} 9901059637477 \mathrm{c} 1 \mathrm{f}$

Wang, J.-J., Jing, Y.-Y., Zhang, C.-F., \& Zhao, J.-H. (2009). Review on multi-criteria decision analysis aid in sustainable energy decision-making. Renewable and Sustainable Energy Reviews, 13(9), 2263-2278. doi:10.1016/j.rser.2009.06.021

White, L., \& Lee, G. J. (2009). Operational research and sustainable development: Tackling the social dimension. European Journal of Operational Research, 193(3), 683-692. doi:10.1016/j.ejor.2007.06.057 